\title{
Evolução do ritmo de sucção e influência da estimulação em prematuros $^{* * *}$
}

\author{
Development of sucking rhythm and the influence of stimulation in \\ premature infants
}

Flávia Cristina Brisque Neiva*
Cléa Rodrigues Leone**

*Fonoaudióloga. Pos-Doutoramento pelo Departamento de Pediatria da Faculdade de Medicina da Universidade de São Paulo. Fonoaudióloga Colaboradora no Hospital Universitário da Faculdade de Medicina de Jundiaí. Endereço para correspondência: Rua Paschoal Guzzo, 530 - Jundiaí - SP - CEP 13207-560 (flaviacbn@yahoo.com.br).

**Médica Pediatra e Neonatologista Professora Livre-docente e Associada do Departamento de Pediatria da Faculdade de Medicina da Universidade de São Paulo.

***Pesquisa Realizada Berçário Anexo à Maternidade do Serviço de Pediatria Clínica, Intensiva e Neonatal - Instituto da Criança "Professor Pedro de Alcântara" Hospital das Clínicas da Faculdade de Medicina da Universidade de São Paulo.

Artigo de Pesquisa

Artigo Submetido a Avaliação por Pares

Conflito de Interesse: não

Recebido em 05.01.2007. Revisado em 01.03.2007; 23.07.2007. Aceito para Publicação em 23. 07.2007.

\begin{abstract}
Background: the sucking development pattern of the preterm newborn (PTNB) in the neonatal period is important for an effective sucking and oral motor development. The establishment of a safe and efficient feeding in pre-term newborns is related to a rhythmic and coordinated sucking. Nonnutritive sucking stimulation can have an influence on the development of sucking and the development of sucking rhythm of pre-term newborns. Aim: to analyze the development of the sucking rhythm, in non-nutritive and nutritive sucking in preterm newborns, as a consequence of non-nutritive sucking stimulation and in terms of corrected gestational age. Method: 95 preterm newborns randomly divided in three groups: Group 1, control group (35 PTNB), did not receive non-nutritive sucking stimulation; Group 2 (30 PTNB), received non-nutritive sucking stimulation using an orthodontic pacifier for premature infants (Nuk®); and Group 3 (30 PTNB), received non-nutritive sucking stimulation using a gloved finger. Results: the mean gestational age was of 30.5 weeks $( \pm 1.57)$, the mean corrected gestational age at the moment of enrollment in the study was of 31.6 weeks $( \pm 1.31)$, and the mean birth weight was of 1.390 grams, with no statistical differences between the groups. The number of sucking bursts and pauses per minute increased by 0.16 per week and the duration of the bursts by 0.81 seconds; the duration of pauses decreased by 3.8 seconds per week while the number of sucks/second was constant, 1.15 and 0.95 for non-nutritive and nutritive sucking, respectively. No statistically significant differences were found between the groups for any of the studied variables. Conclusion: the stimulation of non-nutritive suction in preterm newborns did not modify the post-natal development of sucking rhythm. The process of maturation, represented by the corrected gestational age, was considered the most responsible factor for this process.
\end{abstract}

Key Words: Sucking Behavior; Newborn; Premature; Feeding Methods.

\section{Resumo}

Tema: o desenvolvimento do padrão de sucção em recém-nascido pré-termo no período neonatal é importante não só para o estabelecimento de uma sucção eficiente, mas também para o desenvolvimento motor-oral. A alimentação segura e eficiente do recém-nascido pré-termo está relacionada a uma sucção com ritmo e coordenação. A estimulação da sucção não-nutritiva pode influenciar a evolução do padrão de sucção e o desenvolvimento do ritmo de sucção nos recém-nascidos pré-termo. Objetivo: analisar a evolução do ritmo de sucção, na sucção não-nutritiva e na sucção nutritiva, em função da estimulação da sucção não-nutritiva e do avanço da idade gestacional corrigida. Método: foram envolvidos 95 recém-nascidos pré-termo (RNPT) distribuídos de forma aleatória em três grupos: Grupo 1, grupo controle (35 RNPT), sem estimulação da sucção não-nutritiva; Grupo 2 (30 RNPT), com estimulação da sucção não-nutritiva com chupeta ortodôntica para prematuros Nuk® e Grupo 3 (30 RNPT), com estimulação da sucção não-nutritiva por meio do dedo enluvado. Resultados: os recém-nascidos tinham idade gestacional de nascimento média de 30,5 semanas $( \pm 1,57)$, idade gestacional corrigida ao entrar no estudo média de 31,6 semanas $( \pm 1,31)$ e peso de nascimento médio de 1.390 gramas, sem diferenças estatísticas entre os grupos. O número de eclosões e pausas por minuto aumentou 0,16 a cada semana e a duração das eclosões 0,81 segundos; a duração das pausas diminuiu 3,8 segundos a cada semana e o número de sucções/segundo foi constante, na sucção não-nutritiva 1,15 e na sucção nutritiva 0,95 . Não foram encontradas diferenças estatísticas entre os três grupos em nenhuma das variáveis estudadas. Conclusão: a estimulação da sucção não-nutritiva em recém-nascido pré-termo não modificou a evolução do ritmo de sucção, tendo sido o processo de maturação, representada pela idade gestacional corrigida, o maior determinante desse processo.

Palavras-Chave: Comportamento de Sucção; Recém-Nascido; Prematuro; Métodos de Alimentação.

Referenciar este material como:

1 NEIVA, F. C. B.; LEONE, C. R. Development of sucking rhythm and the influence of stimulation in premature infants (original title: Evolução do ritmo de sucção $\sum 3$ e influência da estimulação em prematuros). Pró-Fono Revista de Atualização Científica, Barueri (SP), v. 19, n. 3, p. 241-248, jul.-set. 2007. 


\section{Introduction}

The sucking of preterm newborns (PTNB) have been studied in relation to the mechanisms and components, effects of non-nutritive sucking (NNS) stimulation and the beginning of oral feeding (Rocha, 2002; Medoff-Cooper et al, 2002; Bühler, 2003; Bühler e Limongi, 2004a; Caetano et al, 2003; Neiva, 2003; McCain, 2003; Fucile et al, 2005; Bromiker et al, 2005; Neiva e Leone, 2006).

Sucking function in PTNB at birth is not established because of their immaturity. In order to achieve complete oral feeding at an earlier age they receive NNS stimulation, contributing to sucking pattern organization, stomatognathic system development and breast feeding (Leone, 2002; Rocha et al. 2002; Delgado e Halpern, 2003; Neiva et al, 2003; Hernandez, 2003a; Neiva, 2004; Bühler e Limongi, 2004b; Miller e Kiatchoosakun, 2004; Neiva e Leone, 2006; Pinelli e Symington, 2006; Pfitscher e Delgado, 2006).

One of the main focus of the assistance to these newborns is the promotion of a securely and efficient oral feeding which is related with sucking ability, and sucking, swallowing and breathing coordination (Leone et al, 2002; Mizuno e Ueda, 2003; Lau et al, 2003; Hernandez, 2003b).

In the sucking function of newborns (NB) the rhythm is of basic importance for the coordination and efficiency of this function. The rhythm is characterized by alternating sucking bursts with pauses that enable the organization and coordination of the NB (Vice et al, 2001).

Several factors can influence the rhythm with which NB perform the sucking bursts and pauses, these include: age, hunger and sucking time, fatigue and satiation, milk flow, sucking pressure and the type of nipple (Hack et al, 1985; Hernandez, 2003b; Scheel et al, 2005).

Based on the importance of sucking rhythm for an adequate feeding of the preterm newborn, and the contribution of NNS stimulation to achieve this function, this study was performed in order to analyze the development of the sucking rhythm in PTNB, with a GA less than 33 weeks, in function of the stimulation of NNS and the corrected GA.

\section{Method}

Randomized clinical study, of intervention, including 95 PTNB that were appropriate for GA, born at the Nursery Annex to the Maternity, Intensive and Neonatal Pediatrics Service, Children's Institute, Clinics Hospital, School of
Medicine - University of São Paulo, from April 2000 to January 2002. The study was approved by the Ethics Commission for Analysis of Research Projects - CAPPesq of the Clinics Hospital and School of Medicine, University of São Paulo (number protocol: 370/01, 09-08-2001). Written informed consent was obtained from the parents or legal guardians.

The inclusion criteria were: GA at birth 33 weeks (defined by the date of the last menstrual period and confirmed by fetal ultrasonography and/or New Ballard Method); postnatal age of at least 2 days of life; APGAR score greater than 6 in the fifth minute of life; and clinically stable, receiving exclusively enteral diet (human milk and/ or formula), through gastric tube, or associated to parenteral nutrition. NB were excluded when presented genetic syndromes, neurological disturbances, motor-oral and congenital malformations.

On entry to the study, the NB were distributed at random into three study groups, in such a way that there was a balanced distribution of GA at birth and corrected GA: Group 1 (G1), Control Group, without specific stimulation offered by the researcher; Group 2 (G2), stimulation of NNS with an orthodontic pacifier NUK for premature infants; and Group 3 (G3) stimulation of NNS with a gloved finger.

After being selected for the study and performing the first evaluation of sucking, the NNS stimulation was executed every day just in Groups 2 and 3, except on weekends, during 10 minutes and concomitant to the feeding through an oral gastric tube during the milk feedings from 9:00, $12: 00$ and $3: 00(\mathrm{pm})$, until the start of the oral feeding.

Before transition to oral feeding, all the NB were submitted on a weekly basis to evaluation of NNS, with a gloved finger. After beginning oral feeding, evaluation of NNS and nutritive sucking (NS) was performed with a mini bottle feeding NEOPAM , using a formula and volume determined by medical prescription. The methods used in the evaluations were detailed in other publication (Neiva e Leone, 2006).

All NNS and NS evaluations, were filmed by the same researcher, according to a standardized method, with a camcorder mounted. The "display time" function (hours, minutes and seconds) of the camcorder was used at all times, so that when analyzing the tapes the timer could be used to determine associations between the duration and the frequency of a certain movement. 
First of all, the researcher looked at the clock in the video registrations to identify the time in which the bursts had begun and, in a second moment, she used a timer to define the duration of every movement. She used to repeat these procedures for every measurement .

Records were kept of: the number and duration of the bursts and pauses; number of sucks per bursts, number of burst and pauses per minute; and the frequency of sucks per second.

In the evaluation of both NNS and NS a sucking rhythm was considered to be present whenever the NB presented sucking bursts alternated with pauses. A pause was considered to end when the NB restarted sucking, started to cry, bit the finger, or when the finger was withdrawn.

\section{Statistical analysis}

The number of NB included in this research followed the criteria of a convenience sample. All PTNB who suited the inclusion criteria were evaluated, during the period from April 2000 to January 2002.

To verify whether there were alterations during the study in relation to the above parameters, the model of adjustment for longitudinal data was used (Singer; Andrade, 2000). Based on the mean profiles observed, the linear curves were adjusted for corrected gestational age (GA.corr), with control of the corrected gestational age on inclusion to the study (GA.corr.base), of the stimulation of NNS (STIM) and the type of evaluation of sucking performed (EV).

Since this was a longitudinal study, the adjusted statistical models included different structures of covariance: unstructured, compound symmetry, autoregressive of order one (Singer; Andrade, 2000). The statistics Akaike Information Criterion (AIC) and the Baysian Information Criterion (BIC) (lowest values) were used as the criterion for choice of the models. The software used were: Excel 2000, SAS 8.0, and SPSS 10.0.

\section{Results}

A total of $95 \mathrm{NB}$ were distributed into three study groups: 35 in the control Group (G1); 30 NB in $\mathrm{G} 2$; and $30 \mathrm{NB}$ in G3. The characteristics of these
NB are shown in Table 1. No statistical differences were observed in the composition of the groups.

Before 32 weeks of corrected GA, it was not identified any pattern in the analyzed measures in any of the 3 groups, therefore, no adjusted statistical model was applied. Thus the statistical models to analyze the data were only adjusted after 32th week.

The mean follow-up of NB during the study was 34.9 days (SD 20.7; range 8-155 days).

Tables 2 and 3 show the statistics regarding each dependent variable(number of bursts and pauses per minute, mean duration of the bursts and pauses, and number of sucks per second) and the effects of NNS stimulation.

No statistically significant differences were found for any of the variables between the 3 groups of NB, therefore the data were grouped together and represented by a single straight line (Graphs 01 to 04).

Graphs were prepared to present the mean profiles (Graphs 01 to 04 ) and Table 4 provides the exact value for each variable at corrected GA weeks 32, 33, 34, 35, 36, 37, 38. 39 and 40.

Regarding the number of bursts and pauses per minute (Graphs 01), it was found that, they increased together with corrected GA, but were greater in NNS when compared to NS. The expected number of bursts and pauses per minute rose by 0.85 , when the evaluation changed from NS to NNS and then increased by 0.16 each week.

In relation to the mean duration of the bursts (Graphs 02), again it was verified that this increased with corrected GA, but, was greater with NS than NNS. The mean duration of the bursts decreased by 12.35 seconds, when the evaluation switched from NS to NNS and then increased by 0.81 seconds, from one week to the next.

The mean duration of the pauses (Graphs 03) showed a decrease in duration, as the corrected GA advanced, and was greater in NNS when compared to NS. The mean duration of the pauses increased by 4.33 seconds, when the evaluation of NS was changed to NNS and then reduced by 3.80 each week.

The mean number of sucks per second (Graphs 04) was constant over time and independent of the corrected GA. This figure was greater in NNS (1.15 sucks per second) when compared to NS (0.95 sucks per second). 
TABLE 1. Characteristics of the NB.

\begin{tabular}{|c|c|c|c|c|}
\hline & $\begin{array}{l}\text { Group 1 } \\
(\mathrm{n}=35)\end{array}$ & $\begin{array}{l}\text { Group 2 } \\
(\mathrm{n}=30)\end{array}$ & $\begin{array}{l}\text { Group } 3 \\
(\mathrm{n}=30)\end{array}$ & $\begin{array}{c}\text { Total } \\
(\mathrm{n}=95)\end{array}$ \\
\hline Sex Male/female & $15 / 20$ & $17 / 13$ & $15 / 15$ & $47 / 48$ \\
\hline GA at birth (weeks) & $30.2(\mathrm{SD} \mathrm{1.82)}$ & $30.6(\mathrm{SD} 1.40)$ & $30.6(\mathrm{SD} 1.45)$ & $30.5(\mathrm{SD} 1.57)$ \\
\hline B irth weight (grams) & $1.389(\mathrm{SD} 404.7)$ & $1.366(\mathrm{SD} 326.1)$ & 1.414 (SD 299.2) & $1.390(\mathrm{SD} 346.4)$ \\
\hline GA corrected (weeks)* & $31.4(\mathrm{SD} \mathrm{1.46)}$ & $31.7($ SD 1.20$)$ & $31.7(\mathrm{SD} 1.26)$ & $31.6(\mathrm{SD} 1.31)$ \\
\hline Postnatal age (days) & $8.5(\mathrm{SD} 7.61)$ & $8.1(\mathrm{SD} 6.47)$ & $7.6(\mathrm{SD} 6.07)$ & $8.1(\mathrm{SD} 6.73)$ \\
\hline
\end{tabular}

$* \overline{\mathrm{GA}}$ at birth + Postnatal age (weeks)

TABLE 2. Result obtained from the model adjusted for every variable studied.

\begin{tabular}{|c|c|c|c|c|c|c|}
\hline \multirow{2}{*}{ Variables } & & \multicolumn{5}{|c|}{ Degrees of } \\
\hline & & Coefficient & S.D. & freedom & t-value & p-value \\
\hline Number of bursts and & Intercept & -3.6819 & 0.9728 & 91 & -3.78 & 0.0003 \\
\hline \multirow[t]{3}{*}{ pauses perminute } & N N S & 0.8491 & 0.0844 & 88 & 10.07 & $<.0001$ \\
\hline & $\mathrm{NS}$ & . & . & . & . & . \\
\hline & GA.corr & 0.1586 & 0.0278 & 574 & 5.70 & $<.0001$ \\
\hline Mean duration of the & Intercept & -10.1089 & 11.4399 & 91 & -0.88 & 0.3792 \\
\hline \multirow[t]{3}{*}{ bursts } & $\mathrm{NNS}$ & -12.3463 & 1.1245 & 88 & -10.98 & $<.0001$ \\
\hline & N S & . & . & . & . & t \\
\hline & G A.corr & 0.8053 & 0.3263 & 574 & 2.47 & 0.0139 \\
\hline Mean duration of the & Intercept & 152.73 & 22.6723 & 91 & 6.74 & $<.0001$ \\
\hline \multirow[t]{3}{*}{ pauses } & NNS & 4.3274 & 1.8881 & 88 & 2.29 & 0.0243 \\
\hline & N S & . & . & . & . & . \\
\hline & GA.corr & -3.8004 & 0.6488 & 574 & -5.86 & $<.0001$ \\
\hline Mean number of & Intercept & 0.9497 & 0.03619 & 91 & 26.24 & $<.0001$ \\
\hline \multirow[t]{2}{*}{ sucks per second } & N N S & 0.1987 & 0.04686 & 88 & 4.24 & $<.0001$ \\
\hline & N S & . & . & & . & . \\
\hline
\end{tabular}

$\mathrm{NNS}=$ nonnutritive sucking; $\mathrm{NS}=$ nutritive sucking; GA.corr= corrected gestational age .

TABLE 3. Statistical methods obtained for every variable studied.

\begin{tabular}{|c|c|c|c|c|c|}
\hline V ariables & Effects & $\begin{array}{c}\text { Numerator degrees } \\
\text { of freedom }\end{array}$ & $\begin{array}{c}\text { Denom in ator } \\
\text { degrees of freedom }\end{array}$ & F-value & p-value \\
\hline Number of bursts and pauses & S T IM & 2 & 88 & 0.49 & 0.6169 \\
\hline \multirow[t]{3}{*}{ per minute } & GA.corr.base & 1 & 88 & 0.79 & 0.3778 \\
\hline & E V & 1 & 88 & 100.19 & $<.0001$ \\
\hline & G A.corr. & 1 & 574 & 29.88 & $<.0001$ \\
\hline \multirow[t]{4}{*}{ Mean duration of bursts } & S T IM & 2 & 88 & 2.02 & 0.1390 \\
\hline & G A corr.base & 1 & 88 & 1.04 & 0.3100 \\
\hline & E V & 1 & 88 & 119.46 & $<.0001$ \\
\hline & G A.corr. & 1 & 574 & 6.6 & 0.0104 \\
\hline \multirow[t]{4}{*}{ Mean duration of the pauses } & S T IM & 2 & 88 & 1.52 & 0.2246 \\
\hline & G A corr.base & 1 & 88 & 0.01 & 0.9036 \\
\hline & E V & 1 & 88 & 5.31 & 0.0236 \\
\hline & G A.corr & 1 & 574 & 32.78 & $<.0001$ \\
\hline Mean number of sucks per & S T IM & 2 & 88 & 0.25 & 0.7768 \\
\hline \multirow[t]{3}{*}{$\operatorname{second}$} & GA.corr.base & 1 & 88 & 0.17 & 0.6769 \\
\hline & E V & 1 & 88 & 17.82 & $<.0001$ \\
\hline & G A.corr & 1 & 574 & 0 & 0.9471 \\
\hline
\end{tabular}

GA.corr $=$ corrected gestational age; GA.corr.base $=$ corrected gestational age on inclusion to the study; STIM $=$ stimulation of NNS; EV = type of evaluation of sucking performed (NNS or NS). 
TABLE 4. Number of bursts and pauses per minute and duration of the bursts and pauses, according to corrected gestational age.

\begin{tabular}{|c|c|c|c|c|c|c|}
\hline \multirow[t]{2}{*}{$\begin{array}{l}\text { Corrected GA } \\
\text { (Weeks) } n=95\end{array}$} & \multicolumn{2}{|c|}{$\begin{array}{c}\text { Number of bursts and } \\
\text { pauses per minute }\end{array}$} & \multicolumn{2}{|c|}{$\begin{array}{l}\text { Mean duration of bursts } \\
\text { (seconds) }\end{array}$} & \multicolumn{2}{|c|}{$\begin{array}{c}\text { Mean duration of pauses } \\
\text { (seconds) }\end{array}$} \\
\hline & NNS & NS & NNS & NS & NNS & NS \\
\hline 32 & 2.24 & 1.39 & 3.31 & 15.66 & 35.45 & 31.12 \\
\hline 33 & 2.40 & 1.55 & 4.12 & 16.47 & 31.65 & 27.32 \\
\hline 34 & 2.56 & 1.71 & 4.93 & 17.28 & 27.85 & 23.52 \\
\hline 35 & 2.72 & 1.87 & 5.74 & 18.09 & 24.05 & 19.72 \\
\hline 36 & 2.88 & 2.03 & 6.55 & 18.90 & 20.25 & 15.92 \\
\hline 37 & 3.04 & 2.19 & 7.36 & 19.71 & 16.45 & 12.12 \\
\hline 38 & 3.20 & 2.35 & 8.17 & 20.52 & 12.65 & 8.32 \\
\hline 39 & 3.36 & 2.51 & 8.98 & 21.33 & 8.85 & 4.52 \\
\hline 40 & 3.52 & 2.67 & 9.79 & 22.14 & 5.05 & 0.72 \\
\hline
\end{tabular}

$\mathrm{GA}=$ gestational age; $\mathrm{NNS}=$ nonnutritive sucking; $\mathrm{NS}=$ nutritive sucking

GRAPH 1. Adjusted model for number of bursts and pauses per minute.

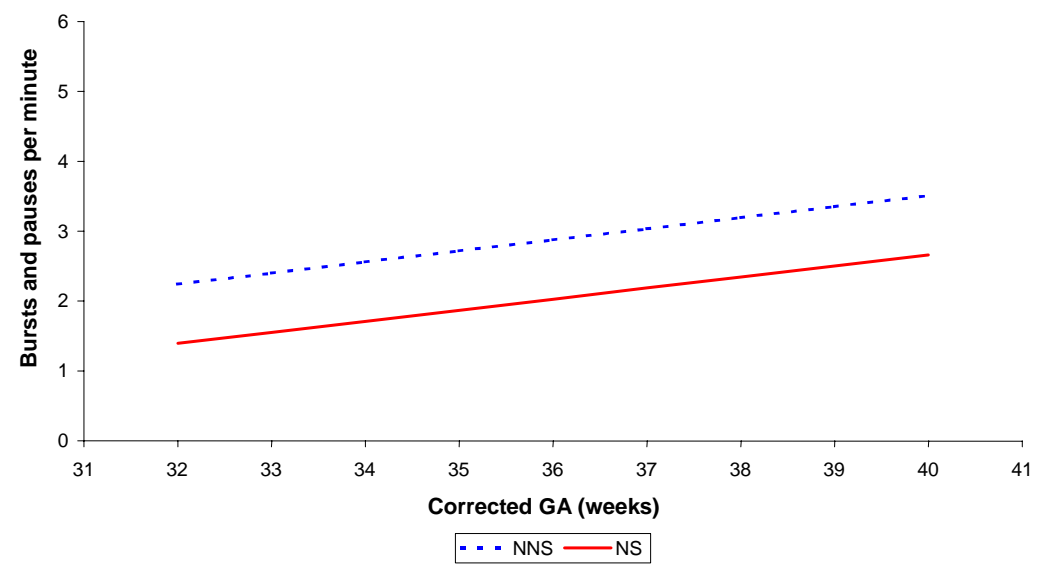

NNS: Non-nutritive sucking

NS: $\quad$ Nutritive sucking

GRAPH 2. Adjusted model for mean duration of the bursts in seconds

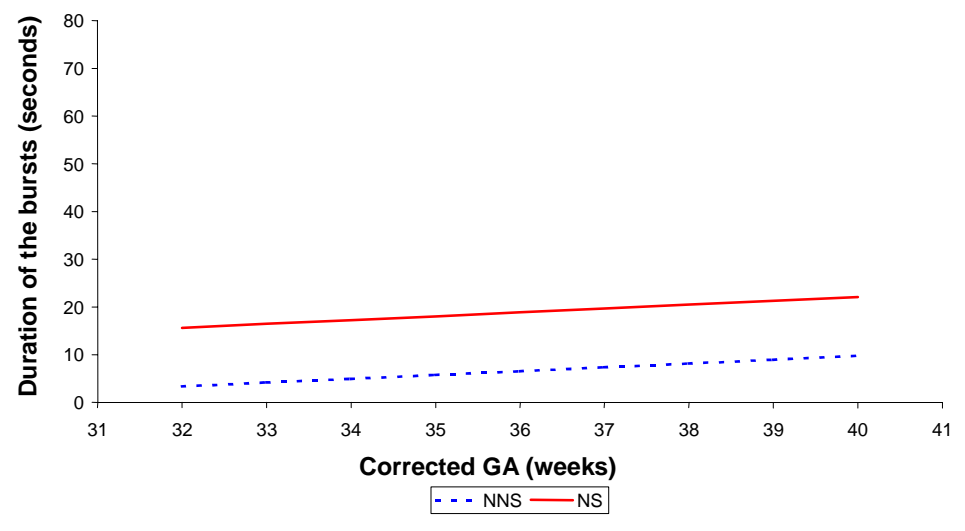

NNS: Non-nutritive sucking

NS: $\quad$ Nutritive sucking 
GRAPH 3. Adjusted model for mean duration of the pauses in seconds.

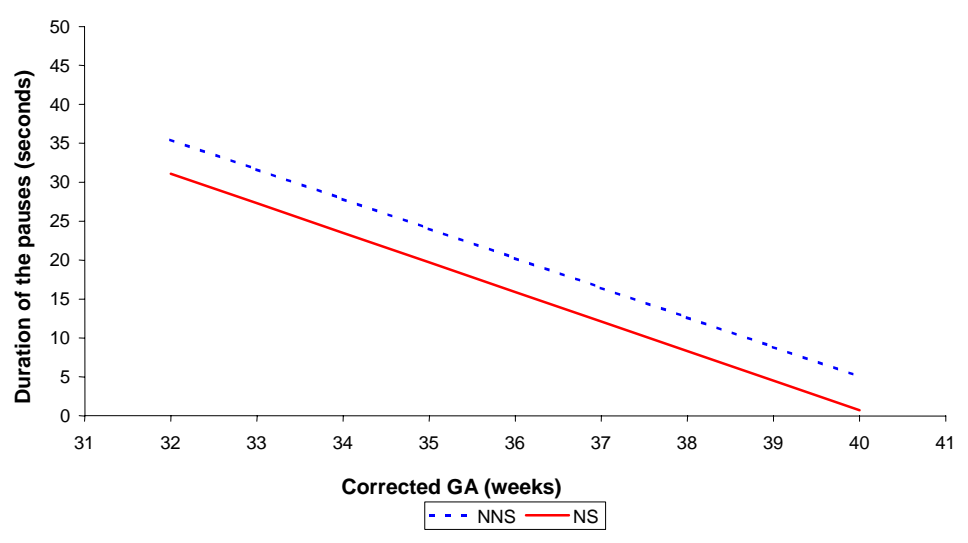

NNS: Non-nutritive sucking NS: Nutritive sucking

GRAPH 4. Adjusted model for number of sucks per second.

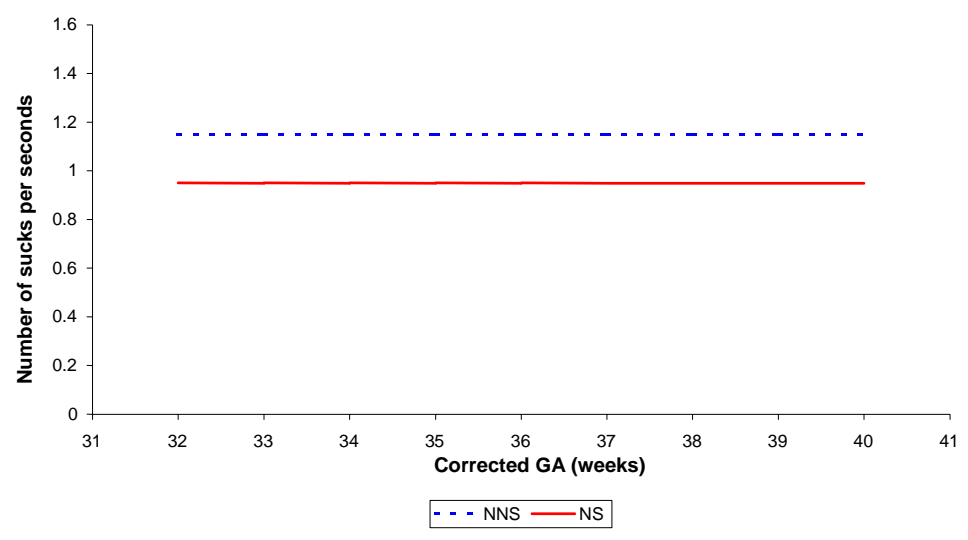

NNS: Non-nutritive sucking

NS: $\quad$ Nutritive sucking

\section{Discussion}

NNS stimulation didn't interfere on the sucking rhythm development in this study, which agrees with Hack et al (1985) observations, in which an intrinsic organization would be the most important factor for rhythm development. Moreover, in literature data show that the sucking rhythm modifies, together with the process of sucking maturation and improves as the corrected GA advances (Gewolb et al, 2001; Qureshi et al, 2002).

Such changes reflect the development of the sucking rhythm, characterized by: an increase in the number of bursts and pauses per minute; an increase in the duration of bursts; and a decrease in the duration of the pauses. Hence, the more mature the NB, the faster and more efficient the sucking action (i.e. more bursts than pauses).

In relation to the number of bursts and pauses per minute, the results are in agreement with the concept that, as the PTNB matures, there is a correspondingly greater frequency of bursts and pauses (Hack et al.;1985).

Likewise, an increase was observed in the mean duration of the bursts ( 0.81 seconds per week) and a decrease in the mean duration of the pauses (3.80 
seconds per week). It is underscored that the decrease in the duration of the pauses was much greater than the increase in the duration of the bursts. This shows that, the lower the gestational age, more time the PTNB needs to rest (pause) to recover from a period of continuous sucking (bursts) and, as the age advances, the time necessary for the pauses decreases, thus demonstrating an evolution of the sucking rhythm as the NB develop and a greater capacity for sucking along time.

This finding corroborates the work of Hack et al. (1985) who reported that NNS utilizing a pacifier for PTNB, showed a decrease in the duration of the pauses as GA advanced, these lasting 15.4 seconds from week 30 to $31 ; 13.2$ seconds from week 32 to 33 ; and 7.1 seconds from week 34 to 35 . Although the authors considered the duration of the bursts stable in these gestational ages,around 4.1 seconds. When comparing their values with those obtained in this research, it was observed that in NNS the duration of the bursts was similar, however, the duration of the pauses was greater among the PTNB studied here. Perhaps the difference detected was due to the type of evaluation instrument used, which was different in the two studies.

Medoff-Cooper et al. (1993) also observed a decrease in the duration of the pauses with the increasing of the GA: 13.95 seconds in 32 weeks, with a progressive reduction to 6.95 seconds by 36 weeks. Once again, it can be noted that these figures were much lower than those obtained in this study.

Even though in 1991, the same authors found that the more mature the NB, the greater the duration of each pause, and in their research, the bursts increased after GA week 33 and the pauses were shorter in NB with 32 weeks of GA (4.7 seconds), these then increased and became more stable between weeks 33 and 35 (7.5 seconds) and in week 36 reached 8.4 seconds.

As for the number of sucks per second, it was verified that this value was constant (1.15 in NNS and 0.95 in NS), independently of the progress of corrected GA. The sucking of the PTNB studied was slower, in that the values found were lower than those reported in the literature: two sucks per second in NNS and one suck per second in NS (McBride; Danner, 1987, Medoff-Cooper et al., 1993). Furthermore, some studies have pointed to a greater number of sucks per second as age increases, so that the sucking becomes faster (Gewolb et al., 2001; Qureshi et al, 2002)..
According to Neiva (1999), in term NB and PTNB with GA 34 weeks, in NNS the number of sucks per second in the initial burst was 1.42 against 1.36 in the intermediate/penultimate burst; the values for NS were, respectively, 1.27 and 1.19. When comparing these values with those obtained in the present study, it was found that in PTNB with GA $<33$ weeks the sucking was slower, which could be related to the fact that these were more immature.

On the other hand, Gewolb et al. (2001) found a variation in the frequency of sucking in NS, and, at around 32 weeks, the value was close to that observed in the present study ( 0.97 sucks/second), increasing to 1.08 sucks per second in GA of 40 weeks.

The results obtained with the variables related to the sucking rhythm, showed differences between the evaluation of NNS and NS. In all the variables, this difference was constant in function of the advance in corrected GA. Besides, the number of bursts and pauses per minute, the mean duration of the pauses, and the number of sucks per second was larger in NNS than in NS. While on the other hand, the mean duration of the bursts was greater in NS than in NNS.

It is possible that these differences could be related to the fact that NS is more physiologic for $\mathrm{NB}$, since it provides the NB with milk and, with the intention of feeding, the NB spends more time sucking than in pauses, likewise the sucking bursts last longer and the pauses are shorter.

Otherwise, Pickler and Reyna(2004) found a positive correlation between the duration of the first burst in NNS and in NS.

As for the number of sucks per second, several authors have affirmed that in NNS this number is twice that of NS: two sucks per second in NNS and one suck per second in NS (Wolf, 1968, McBride; Danner, 1987). In our results, the number of sucks per second was also greater in NNS (1.15) than in NS (0.95), however the difference between them was less than that described in the literature.

\section{Conclusion}

The study variables (number of bursts and pauses per minute, mean duration of the bursts and pauses, and number of sucks per second) were not influenced by stimulation of NNS and, therefore, did not vary between the three groups of NB.

Consequently, it can be suggested that the stimulation of NNS in PTNB did not significantly 
modify the postnatal development of the sucking rhythm and that, probably, the maturation process, represented by the corrected gestational age, is the greatest determinant of this evolution.
The knowledge of sucking rhythm is very important to the evaluation of sucking in PTNB, standing out that it involves objective measurements that may help to sucking evaluation in the PTNB and to the feeding indications.

Acknowledgements Fundação de Amparo à Pesquisa do Estado de São Paulo (FAPESP).

\section{References}

BROMIKER, R.; ARAD, I.; LOUGHRAN, B.; NETZER, D.; KAPLAN, M.; MEDOFF-COOPER, B. Comparasion of sucking patterns at introduction of oral feeding and at term Israeli and American preterm infants. Acta Paediatr. Oslo, v. 94, n. 2, p. 201-204, febr. 2005.

BÜHLER, K. E. C. B. Introdução da alimentação via oral com o uso do copinho em recém-nascidos pré-termo: critérios fonoaudiológicos. 2003. 140 f. Dissertação (Mestrado em Ciências) - Faculdade de Medicina, Universidade de São Paulo, São Paulo.

BÜHLER, K. E. B.; LIMONGI, S. C. O. O uso do copinho como método de alimentação de recém-nascidos prétermo: revisão de literatura. R. Soc. Bras. Fonoaudiol., São Paulo, v. 9, n. 2, p. 115-121, abr.-jun. 2004a.

BÜHLER, K. E. B.; LIMONGI, S. C. O. Fatores associados à transição da alimentação via oral em recém-nascidos pré-termo. Pró-Fono R. Atual. Cient., Barueri (SP), v. 16, n. 3, p. 301-310, set.-dez. 2004b.

CAETANO, L. C.; FUJinAGA, C. I.; SCOCHI, C. G. S. Sucção não-nutritiva em bebês prematuros: estudo bibliográfico. R. Latino-Am. Enf., Ribeirão Preto, v. 11, n. 2, p. 232-236, mar.-abr. 2003.

DELGADO, S. E.; HALPERN, R. Possibilidade de intervenção fonoaudiológica an facilitação do vínculo mãebebê, através do aleitamento materno. Pediatr. Mod., São Paulo, v. 39, n. 3, p. 53-57, mar. 2003.

FUCILE, S.; GIS EL, E. G.; LAU, C. Effect of an oral stimulation program on sucking skill maturation of preterm infants. Dev. Med. Child Neurol., London, v. 47, n. 3, p. 158-162, feb. 2005.

GEWOLB, I. H.; VICE, F. L.; SCHWEITZER-KENNEY, E. L.; TACIAK, V. L.; BOSMA, J. F. Developmental patterns of rhythmic suck and swallow in preterm infants. Dev. Med. Child. Neurol., London, v. 43, n. 1, p. 22-27, jan. 2001.

HACK, M.; ESTABROOK, M. M.; ROBERTSON, S. S. Development of sucking rhythm in preterm infants. Early Hum. Dev., Amsterdam, v. 11, n. 2, p. 133-140, jul. 1985.

HERNANDEZ, A. M. O neonato de alto risco: proposta de intervenção global. In: HERNANDEZ, A. M. Conhecimentos essenciais para atender bem o neonato. São Paulo: Pulso, 2003a. p. 15-23.
HERNANDEZ, A. M. Atuação fonoaudiológica com o sistema estomatognático e a função de alimentação. In: HERNANDEZ, A. M. Conhecimentos essenciais para atender bem o neonato. São Paulo: Pulso, 2003b. p. 4778.

LAU, C.; SMITH, E. O.; SCHANLER, R. J. Coordination of suck-swallow and swallow respiration in preterm infants. Acta Paediatr., Oslo, v. 92, n. 6, p. 721-727, jun. 2003.

LEONE, C. R. Técnicas de alimentação por via digestiva no recém-nascido de muito baixo peso. In: TRINDADE FILHO, O.; ALVES FILHO, N. Clínica de perinatologia: procedimentos e técnicas em neonatologia. Rio de Janeiro: MEAS Editora médica e Científica, 2002. p. 13-19.

LEONE, C. R.; RAMOS, J. A.; VAZ, F. A. O recém-nascido pré-termo. In: MARCONDES, E.; VAZ, F. A. C.; RAMOS, J. L. A.; OKAY, Y. Pediatria básica. 9. ed. São Paulo: Sarvier, 2002. p. 348-352.

McBRIDE, M. C.; DANNER, S. C. Sucking disorders in neurologically impaired infants: assessment and facilitation of breastfeeding. Clin. Perinatol., Philadelphia, v. 14 , n. 1 , p. 109-130, mar. 1987.

McCAIN, G. C. An evidence-based guideline for introducing oral feeding to healthy preterm infants. Neonat. Network J. Neonat. Nurs., Santa Rosa, v. 22, n. 5, p. 45-50, sep.oct. 2003.

MEDOFF-COOPER, B.; VERKLAN, T.; CARLSON, S. The development of sucking patterns and physiologic correlates in very-low-birth-weight infants. Nurs. Res., New York, v. 42, n. 2, p. 100-105, apr. 1993.

MEDOFF-COOPER, B.; McGRATH, J.; SHULTS, J. Feeding patterns of full term and preterm infants at forty weeks post-conceptional age. J. Dev. Behav. Pediatr., Baltimore, v. 23, n. 4, p. 231-236, aug. 2002.

MILLER, M. J.; KIATCHOOSAKUN, P. Relationship between respiratory control and feeding in the developing infant. Sem. Neonatol., London, v. 9, n. 3, p. 221-227, jun. 2004.

MIZUNO, K.; UEDA, A. The maturation and coordination of sucking swallowing and respiration in preterm infants. J. Pediatr., New York, v. 142, n. 1, p. 36-40, jan. 2003. 
NEIVA, F. C. B. Ritmo de sucção: variações na duração das eclosões e das pausas durante a sucção de recémnascidos. In: SOCIEDADE BRASILEIRA DE FONOAUDIOLOGIA. Atualização em voz, linguagem, audição e motricidade oral. São Paulo: Frôntis Editorial, 1999. p. 435-449. (Coleção Soc. Bras. Fonoaudiol.)

NEIVA, F. C. B. Análise evolutiva do padrão de sucção e a influência da estimulação através da sucção nãonutritiva em recém-nascidos pré-termo. 2003. 181 f. Tese (Doutorado em Ciências) - Faculdade de Medicina, Universidade de São Paulo, São Paulo.

NEIVA, F. C. B.; CATTONI, D. M.; RAMOS, J. L. A.; ISSLER, H. Desmame precoce: implicações para o desenvolvimento motor-oral. J. Pediatr., Porto Alegre, v. 79, n. 1, p. 7-12, jan.-fev. 2003.

NEIVA, F. C. B. Neonatologia: papel do fonoaudiólogo no berçário. In: COMITÊ DE MOTRICIDADE ORAL SOCIEDADE BRASILEIRA DE FONOAUDIOLOGIA. Motricidade orofacial: como atuam os especialistas. São José dos Campos: Pulso, 2004. p. 225-234.

NEIVA, F. C. B.; LEONE, C. R. Sucção em recém-nascidos pré-termo e estimulação da sucção. Pró-Fono R. Atual. Cient., Barueri (SP), v. 18, n. 2, p. 141-150, maio-ago, 2006.

PFITSCHER, A. P.; DELGADO, S. E. A caracterização do sistema estomatognático, após a transição alimentar, em crianças prematuras de muito baixo peso. R. Soc. Bras. Fonoaudiol., São Paulo (SP), v. 11, n. 4, p. 215-221, out.-nov. 2006.

PICKLER, R. H.; REYNA, B. A. Effects of non-nutritive sucking on nutritive sucking breathing, and behavior during bottle feedings of preterrm infants. Advances Neonat. Care, Philadelphia, v. 4, n. 4, p. 226-234, aug. 2004.
PINELLI, J.; SYMINGTON, A. Non-nutritive sucking for promoting physiologic stability and nutrition in preterm infants: cochrane review. Cochrane Database Syst. R., Oxford, v. 19, n. 4, CD001071, oct. 2005.

QURESHI, M. A.; VICE, F. L.; TACIAK, V. L.; BOSMA, J. F.; GEWOLB, I. H. Changes in rhythmic suckle feeding patterns in term infants in the first month of life. Dev. Med. Child. Neurol., London, v. 44, n. 1, p. 34-39, jan. 2002.

ROCHA, A. D. Efeitos da sucção não-nutritiva durante a alimentação enteral em crianças prematuras. 2002. 122 f. Dissertação (Mestrado em Saúde da Criança e da Mulher) - Instituto Fernandes Figueira, Fundação Oswaldo Cruz, Rio de Janeiro.

ROCHA, A. D; MOREIRA, M. E. L.; RAMOS, J. R. M.; COSTA, A. M.; MALLET, N. R. Efeitos da sucção nãonutritiva durante a alimentação enteral nos parâmetros temporais da sucção de neonatos pré-termo. J. Bras. Fonoaudiol., Curitiba, v. 3, n. 13, p. 298-303, out.-dez. 2002.

SCHEEL, C. E.; SCHANLER, R. J.; LAU, C. Does the choice of bottle nipple affect the oral feeding performance of very-low-birthweight (VLBW) infants? Acta Paediatr., Oslo, v. 94, n. 9, p. 1266-1272, sep. 2005.

SINGER, J. M.; ANDRADE, D. F. Analysis of longitudinal data. In: SEN, P. K.; RAO, C. R. Handbook of statistics. Amsterdam: North Holland, 2000. p. 115-160.

VICE, F. L.; BOSMA, J. F.; GEWOLB, I. H. Developmental changes in repiratory patterning and synchronization during rhythmic suckle feeding in premature infants. Pediatr. Res., Baltimore, v. 49, n. 4, p. 344a, mar. 2001. (pt. 2). 